subnormality and were at local health authority training centres, in subnormality hospitals, or at home. And, for good measure, it must be mentioned that in 19651,172 girls under the age of 16 years had an illegitimate baby ; 190 boys and girls under the age of 16 years were treated at venereal diseases clinics, but very few of them were known to be at school ; about 63,000 of those under 17 years of age were found guilty of indictable offences (mainly larceny and breaking and entering); and almost 70,000 of those under the age of 18 years were in the care of local authorities on 31 March 1967.

They add up to a formidable total, and present educational, medical, and social problems of greater or less degree; their management depends on a close working partnership between education, medicine, and the other social services. They are the very stuff of present-day paediatrics and will be the subject of my second lecture. But we must keep all this in perspective and remember that although many schoolboys and schoolgirls have defects and disabilities that retard their development and education, and some are permanently incapacitated, the big majority are healthy, without handicap of any kind, and are well-behaved; and this I emphasize. There always have been those who have criticized the younger generation, and so it is today; but I am not of their company. In my opinion the present generation of children and young people compare favourably with their predecessors and I believe that our society will be safe in their hands.
REFERENCES

Trevelyan, G. M., British History in 19th Century, 1944, p. 114. London.

Trevelyan, G. M., British History in 19th Century, 1944, p. 129.

s Trevelyan, G. M., British History in 19th Century, 1944, p. 144. London.

- Himes, N. E., Place on Population, p. 252, 1930. London.

George, M. Dorothy, London Life in 18 th Century, 1925, p. 406. London.

- Hammond, J. L., and Hammond, Barbara, The Town Labourer, 1941, p. 76. London.

7 Simon, J., Public Health Reports, 1887, 1, 47.

8 Adamson, J. W., Short History of Education, 1919, p. 220. Cambridge.

- Adamson, J. W., Short History of Education, 1919, p. 220. Cambridge.

10 Winslow, C. E. A., Conquest of Epidemic Disease, 1943, p. 341. Princeton.

${ }^{11}$ Griffith, A. S., Tubercle (Lond.), 1937, 18, 529

${ }_{12}$ McDougall, J. B., Tuberculosis, 1949, p. 380 . Edinburgh.

${ }^{13}$ General Register Office, Report on Hospital In-patient Enquiry, 1962, 1966, Pt. 1, pp. 130-134. H.M.S.O., London.

${ }^{14}$ Central Statistical Office, Monthly Digest Statistics, 1967, No. 259, p. 45. H.M.S.O., London.

15 Report of Subcommittee on Standards of Housing Fitness, 1966, p. 56. H.M.S.O., London.

16 Report on Hospital In-patient Enquiry, 1963, 1967, p. 1. H.M.S.O., London.

17 Murray, I. G., Mth. Bull. Minist. Hlth Lab. Serv., 1966, 25, 210.

18 Mellanby, K., Scabies, 1943, p. 45. London.

10 Shrank, A. B., and Alexander, Suzanne L., Brit. med. F., 1967, 1, 669.

${ }^{20}$ Logan, W. P. D., and Cushion, A. A., Medical and Population Subjects, No. 14, Morbidity Statistics from General Practice, vol. 1 General, 1958. H.M.S.O., London.

[The second lecture will appear in next week's issue.]

\title{
Antifertility Effect of Continuous Low-dosage Oral Progestogen Therapy
}

\author{
JUAN ZAÑARTU, M.D.; GUILLERMO RODRIGUEZ-MOORE, M.D. ; MARCOS PUPKIN, M.D. ; \\ ORIANA SALAS, M.D. ; RODOLFO GUERRERO, B.CH.
}

Brit. med. F., 1968, 2, 263-266

Inhibition of fertility with progesterone and 19-norsteroids was first reported by Pincus et al. (1958); it was evident that progestogens in adequate dosage inhibited ovulation. The use of injectable long-acting progestogens without oestrogens for fertility control was reported by us in 1965 . It was shown that medroxyprogesterone acetate 250 to $500 \mathrm{mg}$. intramuscularly induced ovulation inhibition for a period of at least six months (Zañartu and Navarro, 1965 ; Zañartu et al., 1965). However, it was soon observed that in subjects receiving one single injection fertility was still inhibited for two or more months even after ovulation was re-established, as shown by the existence of corpus luteum under macroscopic and microscopical examination of the ovaries (Zañartu et al., 1965). It was felt that the effect of injected progestogens induced the inhibition of fertility during this period by modifying other factors more sensitive to lower doses (endometrium, cervical glands, etc.).

The observations reported by Martinez-Manautou et al. $(1965,1966,1967 \mathrm{a})$ and by Rudel et al. (1965) of inducing contraception with daily microdosages of progestogen have opened a new approach to fertility control without interfering with the hypothalamic-pituitary-ovarian axis, at least in respect of ovulation. From a historical viewpoint it is interesting to note the gradual reduction in the steroid dosage required to obtain fertility inhibition in women. The initial pioneering clinical work from Pincus et al. (1958) used $10 \mathrm{mg}$. of norethynodrel with $150 \mu \mathrm{g}$. of ethinyloestradiol 3-methyl ether, compared with the progestogen microdosage $(0.5 \mathrm{mg}$. of chlormadinone acetate) now being reported as successful in inhibiting fertility.

The continuous "non-stop" form of administration may be particularly acceptable and be easier to follow in subjects from low socio-economic and educational levels. The low cost and easy handling of the treatment is also attractive for family planning purposes in this population. The present report therefore attempts to explore the acceptability and clinical effectiveness of the therapy in fertile healthy young women from low socio-economic and educational levels as compared with a group of well-to-do educated subjects.

\section{Material and Methods}

From 1965 to March 1967390 fertile healthy young women from two different socio-economic and educational groups were studied. Forty-five were educated and came from families with an above-average income. The remaining 345 were from low-income groups. Chlormadinone acetate $0.5-\mathrm{mg}$. tablets were given daily without interruption. The therapy was offered to women when conventional combined or sequential

\begin{tabular}{|c|c|c|c|c|c|}
\hline Age & Group A & Group B & $\begin{array}{c}\text { Fertility } \\
\text { (No. of } \\
\text { Pregnancies) }\end{array}$ & Group A & Group B \\
\hline $\begin{array}{l}16 \text { to } 20 \text { years } \\
21 \text { " } 30 \text { " } \\
31 \text { " } 40 \text { "” } \\
41 \text { or more " }\end{array}$ & $\begin{array}{r}26 \\
199 \\
117 \\
3\end{array}$ & $\begin{array}{r}\overline{23} \\
21 \\
1\end{array}$ & $\begin{array}{rll}1 & \text { to } 4 & \\
5 & \Rightarrow & 8 \\
9 & \# \\
13 & \text { or more } & 0\end{array}$ & $\begin{array}{r}146 \\
124 \\
58 \\
17\end{array}$ & $\begin{array}{r}23 \\
20 \\
2 \\
-\end{array}$ \\
\hline
\end{tabular}

Group $\mathrm{A}=345$ clinical patients. Group $\mathrm{B}=45$ private patients. 
oral contraception was either poorly tolerated or not acceptable to the user. One hundred and ten women started treatment after parturition during the time of amenorrhoea and lactation, and 250 women were already menstruating. Table I shows the age and fertility of our patients before treatment. All were given simple instructions to swallow one tablet daily and refrain from intercourse during the first seven to 10 days to prevent conception.

In all subjects Papanicolaou smears were taken at regular intervals, while a complete physical and pelvic examination was made. All women were instructed to keep menstrual records, registering the days of bleeding and amount of flow.

Drug tolerance and side-effects, uterine bleeding, and menstruation were compared with the conditions existing before therapy or when the subjects had been on conventional oestrogen-progestogen contraception. All women were offered an opportunity to change the contraceptive therapy if not satisfied. In a selected group of these women vaginal cytology, cervical mucus and Huhner-Sims post-coital test, endometrial biopsy, and urinary excretion of pregnanediol were studied with techniques described elsewhere (Sulimovici et al., 1965 ; Zañantu et al., 1965 ; Rosenberg and Zañartu, 1967). In 12 subjects surgical exploration of internal organs and ovarian histological study of tissue obtained by wedge biopsy were carried out.

Up to March 1967 there were 3,400 observed months ; 322 women had been under therapy from 2 to 12 months and 68 from 13 to 20 months.

\section{Effectiveness}

\section{Results}

Twenty-four undesired pregnancies occurred. In 11 the cause evidently was a failure to use the method properly (patient's failure). These subjects missed their medication for 3 to 10 or more days owing to forgetfulness or other causes. Fertility was promptly re-established in the same or subsequent cycle.

Pregnancy occurred in 13 women despite apparently correct use of the method (drug failure). All were young fertile subjects. They tolerated the method quite well and their menstrual cycles were not disturbed. In three women in whom pregnancy occurred during the first or second month of use the method was employed after discontinuing oral sequential contraception. Table II summarizes the relation between therapy and pregnancy. Among the private patients there were two drug failures and no failures among patients in 460 months of use.

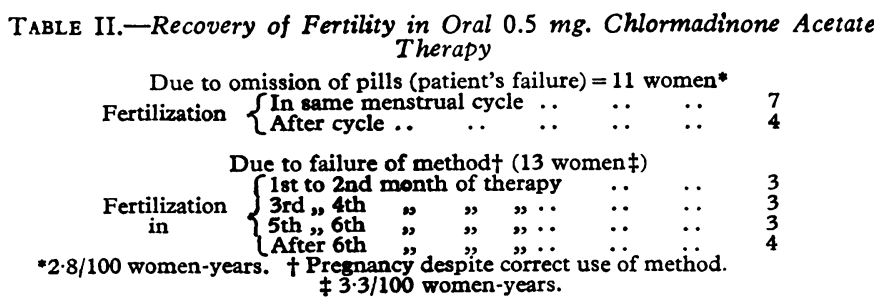

\section{Tolerance and Side-effects}

Tolerance of oral chlormadinone was surprisingly good, particularly in subjects who had previously received conventional combined or sequential oral contraception and had requested a change because of side-effects. Relief of these side-effects was almost immediate in these patients. Excellent tolerance was described by 253 women $(64 \%)$. Mild to moderate frontal or occipital headaches, occasionally accompanied by dizziness or anxiety, were reported by 137 patients, but in only four were these symptoms severe. Another infrequent complaint was increase of pre-existing symptoms of dyspepsia, particularly in subjects with chronic gall bladder disease (15 women).

The main disturbance was in uterine bleeding and menstrual cycles: amenorrhoea or intermenstrual spotting (Table III). It is worth noting that no pregnancies occurred in subjects with irregular or prolonged cycles or amenorrhoea. In fact, failures of the method were seen only in women with quite regular and normal uterine bleeding.

TABLE III.-Uterine Bleeding and Menstrual Cycle Disturbances Associated with Oral Continuous Chlormadinone Contraception in 390 Women

Uterine bleeding:

Normal uterine bleeding*

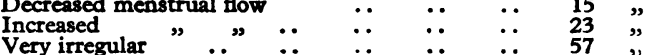

Menstrual cycles:

Normal menstrual cycles* .. $\quad . \quad \ldots \quad$.. $\quad$.. 243 women

Occasional or constant amenorrhoea $\quad \ldots \quad \ldots \quad{ }_{58}$,

$\begin{array}{lllll}\text { Prolonged cycles (more than } 35 \text { days) } & \because & \because & 22 & \text { " } \\ \text { Short cycles (less than } 25 \text { days) }\end{array}$

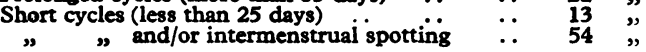

Dysmenorrhoea:

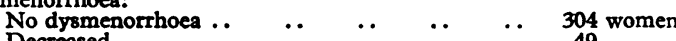

Decreased

Increased

* " Normal "uterine bleeding and/or menstrual cycles means no change from the accepted normal average and the patient's own pattern before contraceptive therapy was used.

When the irregularity was annoying to the patient oral oestrogen tablets were given as well in order to obtain bleeding and cycle regulation in 47 women. Under these circumstances an effective dosage seemed to be 20 to $40 \mu \mathrm{g}$. of ethinyloestradiol or its 3-methyl ether (mestranol), as well as 2.5 to $5 \mathrm{mg}$. of conjugated oestrogens for 7 to 10 days of each calendar month in addition to the contraceptive compound: this scheme would be repeated for three to six months, after which the menses apparently resumed normal patterns. This method resembles a " reverse sequential" scheme except that all patients continued daily chlormadinone therapy. It was feared that additional oestrogens would promote fertilization by changing the cervical mucous and endometrial patterns. However, no pregnancies have yet been reported in these subjects. We were successful in correcting the alterations in 27 women.

Repeated pelvic examinations showed no appreciable morphological changes except that in three women mild to moderate enlargement of one ovary was noticed.

\section{Acceptability}

The acceptance of this therapy, particularly by subjects previously using combined or sequential contraception with poor tolerance, has been impressive. To all subjects under continuous $0.5-\mathrm{mg}$. chlormadinone tablets the choice was offered of changing to other oral, to injectable, or to intrauterine contraception. Of 47 women who discontinued using the method, however, only 17 requested other forms of contraception (Table IV).

Table IV.-Reasons for Abandoning Therapy in 47 Women

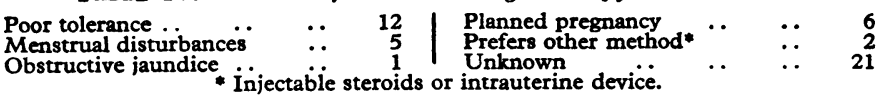

Drop-outs were usually related to menstrual irregularities, mainly prolonged cycles or amenorrhoea, accompanied by fear of pregnancy. Also, reasons given were symptoms such as headaches or digestive troubles (increase of dyspepsia and pain in subjects with chronic gall bladder disease), or both.

Subjects from group A tended to abandon oral therapy or frequently omitted to take tablets, resulting in unwanted pregnancies. We expected more complaints about the method owing to menstrual disturbances from the better-educated subjects in group B. Despite the group being small the therapy was sur- 
prisingly well accepted by these women as well. Most of them (40) had previously received conventional combined or sequential therapy; they reported better tolerance, which was very welcome. Only two women from group B discontinued the method because of menstrual disturbances, while 12 required accessory oestrogen therapy.

\section{Discussion}

It has been shown by urinary pregnanediol excretion and culdoscopy that continuous oral low-dosage chlormadinone acetate does not consistently interfere with the hypothalamic, pituitary, and ovarian relations conditioning ovulation, but that ovulation often persists. It was suggested that chances in the endometrium and/or the receptivity to sperm of cervical mucus were significant (Martinez-Manautou et al., 1965, 1966 ; Rudel et al., 1965, 1966).

In 12 patients under treatment ovulation and corpus luteum formation were investigated by direct gross and microscopical examination of the ovaries at laparotomy. Sperm penetration and ascent, and endometrial morphology were also investigated. These findings have been reported in part elsewhere (Zañartu, 1964, 1967 ; Zañartu et al., 1965, 1967 ; Rosenberg and Zañartu, 1967), and are described in the paper which follows (Zañartu et al., 1968).

Huhner-Sims post-coital tests performed from 2 to 12 hours after coitus in fertile healthy women receiving $0.5 \mathrm{mg}$. chlormadinone continuous therapy have shown that this dosage induces changes in mucous viscosity and leucocyte content, and also impairs fern crystallization and decreases sperm mobility. However, some tests performed between the 10th and 20th days of the cycle revealed sperm motility described as "fair" and " good" (Zañartu, 1964, 1967). Mucous hostility to spermatozoa was therefore not consistently affected in subjects under this therapy. Studies on the effect of progestogens in the biochemical composition of the cervical mucous are needed for better understanding of this mechanism.

Endometrial histology was evaluated by biopsies performed at different weeks of the menstrual cycle, particularly at the premenstrual period. Morphology similar to the patterns found in normal non-treated ovulatory women were observed. However, subjects with prolonged or irregular uterine bleedings had signs of inactive endometrium (Rosenberg and Zañartu, 1967). There was considerable individual variation of response.

Twelve subjects had their ovaries, Fallopian tubes, and uterus examined at surgical operation. Ovulation, as shown by the presence of a corpus luteum and urinary excretion of pregnanediol, had evidently occurred in six. Antiovulatory effects were apparent in the remaining subjects. Flushings from Fallopian tubes removed a few hours after coitus did not contain sperm, though there is as yet no information available about whether this therapy was responsible.

The studies suggest an interference with cervical glands, endometrium, and possible sperm transport, but with ovulation frequently preserved.

\section{Advantages of this Therapy}

The first advantage to be mentioned is the ease of management. With simple instructions therapy may be started immediately after initial examination and at any moment post partum or during the menstrual cycle. There has been no deleterious effect when the patient inadvertently received this progestogen while already pregnant. This occurred in three women without evidence of damage to the newborn.

Secondly, if properly used, the method is effective, though our failure rate seems somewhat higher than those reported by others (Martinez-Manautou et al., 1965, 1966, 1967b); Rudel et al., 1965).
Thirdly, tolerance to the drug is good. Most of the women in the present study had already shown intolerance to other forms of oral contraception. Their tolerance of this method is therefore particularly noteworthy. Irregular bleeding or amenorrhoea, or both, can be corrected by means of accessory oral oestrogens during few cycles if desired. The incidence of these complaints seems higher in women who had irregular uterine bleeding before marriage.

Fourthly, lactation is apparently not interfered with; occasionally it is increased by oral or injectable progestogens, when used without oestrogens (Gomez-Rogers et al., 1967).

Fifthly, ovulation and endocrine ovarian function are usually preserved. Presumably the hypothalamic-pituitary axis is less disturbed.

Sixthly, recovery of fertility is almost immediate, either in the first or second cycle after discontinuation of therapy.

Seventhly, severe side-effects are the exception. In our experience specialized medical care was seldom required because of complications. In young healthy subjects medical examinations do not seem necessary more than once a year.

Eighthly, the low cost of the therapy is most important for developing nations with limited resources for family planning.

Finally, recent observations (Orellana-Alcalde and Dominguez, 1966, 1968) on subjects who have suffered from idiopathic jaundice or intrahepatic cholestasis during their pregnancy should be noted. These symptoms relapsed while combined or sequential oral contraception was used. Under chlormadinone acetate therapy, however, results of liverfunction tests (serum bilirubin and transaminases, bromsulphalein excretion) have remained within normal values.

\section{Disadvantages of Therapy}

The disadvantages should also be listed. Firstly, it is an oral method. Illiterate subjects or women from low educational levels of the population have a higher incidence of not taking their tablets. Undesired pregnancies follow, often resulting in induced abortion. Secondly, even when the method is properly used effectiveness is not total. Failures seem to occur in subjects changing to this method after the use of sequential oral contraceptives.

\section{Summary}

Chlormadinone acetate $0.5 \mathrm{mg}$. was given daily as a continuous "non-stop" oral contraceptive to 390 young fertile healthy women during 3,400 months. Tolerance was good, systemic side-effects being infrequent. Uterine bleeding, menstrual cycle disturbances, and amenorrhoea were the main complaints against the method, but were seldom severe. In 47 women accessory oral oestrogen therapy was added to the daily progestogen to correct these alterations.

The method can be started at any time after parturition or abortion; it does not interfere with lactation. Its use is simple and does not require complicated instructions. The method seldom interferes with ovulation. In a few of the 12 subjects who underwent surgery while under therapy, fresh corpora lutea were observed. Urinary excretion of pregnanediol also indicated progesterone secretion.

Studies have suggested possible interference with sperm ascent. No sperms have been recovered from the fluid flushing from Fallopian tubes obtained a few hours after coitus.

Fertility is re-established immediately after therapy is discontinued, either in the first or the second cycle.

Twenty-four undesired pregnancies have been observed during this period. They were due to improper use of the

\section{证

\section{.}


method in 11 women; in 13 subjects who claim they used the method correctly apparently the method failed.

The method is well tolerated and accepted by subjects who had experienced previous intolerance to conventional oral combined or sequential therapy. Its low cost and ease of administration makes it of interest to developing countries with limited resources for family planning.

This work was supported in part by a grant from the Ford Foundation to the University Maternity Hospital, University of Chile Medical School, for the "University Programme for Research and Training in Reproductive Biology and Human Fertility Control."

We are indebted to Syntex Laboratories Inc., Palo Alto, California (U.S.A.), and E. Merck-Darmstadt (Germany) for the generous supply of chiormadinone 0.5 -mg. tablets.

Requests for reprints should be addressed to Dr. J. Zañartu, Departamento de Fertilidad, Casilla 6637, Santiago, Chile.

\section{REFERENCES}

Gomez-Rogers, C., Ibarra, A., and Guiloff, E. (1967). Report to VIII World I.P.P.F. Congress (Santiago, Chile), April.
Martinez-Manautou, J., Giner-Velazques, J., Cortes-Gallegos, V., Casasola, J., Aznar, R., and Rudel, H. W. (1965). Excerpta Medica International Congress Series, 112, 157.

Martinez-Manautou, J., Cortez, V., Giner, J., Aznar, R., Casasola, J., and Rudel, H. W. (1966). Fret. Steril., 17, 49.

Martinez-Manautou, J., et al. (1967a). Brit. med. f., 2, 730.

Martinez-Manautou, J., Giner, J., Aznar, R., Lozano, M., and Rudel, H. W. (1967b). Report to VIII World Congress I.P.P.F. (Santiago, Chile), April

Orellana-Alcalde, J. M., and Dominguez, J. P. (1966). Lancet, 2, 1278.

Orellana-Alcalde, J. M., and Dominguez, J. P. (1968). Personal communication. To be reported.

Pincus, G., Rock, J., and Garcia, C. R. (1958). Ann. N.Y. Acad. Sci.,

Rosenberg, D., and Zañartu, J. (1967). Rev. méd. Chile, 95, 501.

Rudel, H. W., Martinez-Manautou, J., and Maqueo-Topete, M. (1965) Fert. Steril., 16, 158.

Rudel, H. W., and Kincl, F. A. (1966). Acta endocr. (Kbh.), Suppl. No. $105,51,7$.

Sulimovici, 'S., Lunenfeld, B., and Shelesnyak, M. C. (1965). Acta endocr. (Kbh.), 49, 97.

Zañartu, J. (1964). Int. F. Fert., 9, 225.

Zañartu, J. (1967). Excerpta Medica International Congress Series, 133, 704.

Zañartu, J. and Navarro, C. (1965). Excerpta Medica International Congress Series, 112, 150 .

Zañartı,, J., Rosenberg, D., and Puga, J. (1965). Report to VI Pan American Congress of Endocrinology, Mexico City, October.

Zañartu, J., Pupkin, M., Rosenberg, D., Puga, J. A., and Guerrero, R. (1967). Rev. méd. Chile, 95, 512 .

\title{
Effect of Oral Continuous Progestogen Therapy in Microdosage on Human Ovary and Sperm Transport
}

\author{
JUAN ZAÑARTU, M.D. ; MARCOS PUPKIN, M.D. ; DAVID ROSENBERG, M.D. \\ RODOLFO GUERRERO, B.CH.; ROGELIO RODRIGUEZ-BRAVO, M.D. \\ MARCIAL GARCIA-HUIDOBRO, M.D. ; JUAN A. PUGA, M.D.
}

Brit. med. F., 1968, 2, 266-269

Therapy with oral continuous progestogens in microdosage is an effective and simple contraceptive steroidal method (Martinez-Manautou et al., 1965, 1966, 1967 ; Rudel et al., 1965). However, its mechanism of action has not yet been fully clarified. It has been claimed that ovulation is usually preserved, and eventually the main factors conditioning the contraceptive effect are the changes induced on the secretion of the cervical glands (Zañartu, 1964, 1967 ; Martinez-Manautou et al., 1966, 1967).

This paper attempts to throw further light on the possible antifertility mechanism of this method.

\section{Material and Methods}

Twelve young fertile women underwent surgical operation while receiving oral continuous chlormadinone acetate $0.5 \mathrm{mg}$. contraceptive therapy for 4 to 19 months. Their ages ranged from 32 to 39 years (Table I).

Before surgery the antioestrogenic effect of the compounds was evaluated by serial vaginal cytology, cervical mucus tests (its tolerance to sperm as seen 6 to 12 hours after coitus), and endometrial histology in the same and/or preceding cycle to the operation. Vaginal smears and Huhner-Sims post-coital tests were done between the $7 \mathrm{th}$ and $10 \mathrm{th}, 13 \mathrm{th}$ and $16 \mathrm{th}$, and 22nd and 26th days of the cycle. Endometrial tissue was obtained by biopsy around the 22nd to the 26th day (Noyes et al., 1950). The 24-hour urinary pregnanediol excretion was studied between the 8 th and 14th days and the 22nd and 26th days on those subjects with regular cycles (Sulmovici et al., 1965).

Laparotomy was done on the 14th, 15 th (four women), 16th, $17 \mathrm{th}, 19 \mathrm{th}, 21 \mathrm{st}, 26 \mathrm{th}$, and $27 \mathrm{th}$ days of the cycle and in one subject who was amenorrhoeic, the latter symptom persisting after lactation was discontinued. The object was tubal sterilization in 10 patients, and treatment of non-gynaecological conditions in two. Careful macroscopic examination of the uterus, Fallopian tubes, and both ovaries was carried out. Then a substantial wedge biopsy specimen was taken from an area of the gonad where there was definite evidence of some functional activity (mature follicle, cystic follicle, follicular cyst, corpus luteum, etc.). The ovarian tissue was processed for conventional haematoxylin-eosin and van Gieson staining methods in serial sections, as well as histochemical identification of carbohydrates and steroid-converting enzymes. For this purpose part of the biopsy specimen was immediately frozen and sectioned on a cryostat at $-20^{\circ} \mathrm{C}$, $16 \mu$, and incubated at $37^{\circ} \mathrm{C}$. Techniques were used for demonstration of lactic, succinic, glucose-6-phosphate, 3 - $\beta$-hydroxysteroid, and $20-\alpha$-hydroxysteroid dehydrogenases. Some ovarian sections were also stained with Sudan black for total lipids (Pupkin et al., 1966).

The appearance of both ovaries, particularly in respect of their size, aspect and number of cysts, signs of ovulation, and presence of corpora lutea, was carefully recorded. The germinal epithelium, ovarian cortex stroma, characteristics of follicles, cysts, with or without luteinization of the theca interna, were also studied histologically.

Follicles were classified as: "primary" (I), when the egg-cell was surrounded by a single layer of flat epithelium; "secondary" (II), if one or more stratified granulosa cell layers were present ; " tertiary" (III) or vcsicular follicles, with antrum and fluid; Graafian and "ruature" follicles, containing numerous layers of granulosa cells, a developed, eccentric

\footnotetext{
* Department of Fertility and Laboratory of Morpho-Physiology, University Maternity Hospital, University of Chile Medical School, Santiago, Chile.
} 